\title{
MEPE GALON: Counseling Method of Semi- Modern Salt Making in an Effort to Realize the Education Community Concerned with the Salt Crisis
}

\author{
Putri Rosilia \\ Faculty of Education \\ State University of Malang \\ Malang, Indonesia \\ putrirosi76@gmail.com \\ Ika Febriana Wati \\ Faculty of Education \\ State University of Malang \\ Malang, Indonesia \\ febrianabiebs6@gmail.com
}

\author{
Putri Septi Mawar Dianti \\ Faculty of Education \\ State University of Malang \\ Malang, Indonesia \\ putriseptimd@yahoo.co.id \\ Yuniawatika \\ Faculty of Education \\ State University of Malang \\ Malang, Indonesia \\ yuniawatika.fip@um.ac.id
}

\begin{abstract}
Salt production is one of the issues that concern the government because of the salt crisis in bad weather. As a result, many farmers are unable to produce maximally resulting in saltiness. For industrial salt in 2018 imported 3.7 million tons. While the overall yield of salt produced by farmers ranged from 1.43 million tons, mostly only for consumption of salt. Therefore, triggered a method to overcome them. Writing this article aims to describe methods that serve to improve the quality and quantity of industrial salt production and to minimize the dependence of imported salt. The applied method still adopts conventional salt making methods with the addition of filtration, greenhouse effect, geoisolator, ulir system, and chemical addition to reduce unnecessary substance content.
\end{abstract}

\section{Keywords - salt crisis, semi-modern method, imported salt}

\section{INTRODUCTION}

Indonesia is a maritime country with the second longest coastline in the world. The sea area in Indonesia reaches 5.3 thousand $\mathrm{km}^{2}$. This has become a huge potential in the field of food and industry that utilizes resources from the sea. But in fact, on the ground, Indonesia is still experiencing a shortage of food from its marine products. One of them is the need for salt. This is because of the long coastline in Indonesia not all can be utilized for industrial salt production.

In Indonesia there are 10 potential areas that can be used as salt ponds, although not all coastlines in Indonesia can be used as salt ponds, but with these potentials, the government can maximize the existing potential so that Indonesia does not need to import salt anymore. One effort that can be done is to improve existing technology.

Salt is one of the national vital needs. Aside from being used as a material for salt consumption as an industrial material. The content of $\mathrm{NaCl}$ in salt is a major factor in the need for salt in human life. Physically, salt is a crystalline white solid that is a collection of compounds with the largest portion of sodium chloride (> 80\%) and other compounds such as magnesium chloride, magnesium sulfate, calcium chloride, and others. Salt has hygroscopic characteristics which means it is easy to absorb water, bulk density is 0.8 0.9 and the melting point is at a temperature level of $8010 \mathrm{C}$.

The Ministry of Industry in its website www.kemenperin.go.id stated that the national salt demand reached 4.5 million tons in 2018. With details of consumption salt needs of 800 thousand tons and 3.7 million tons as industrial salt needs [1].

This considerable industrial salt requirement is based on the rapid development of the petrochemical and paper industries which require salt to reach 2.5 million tons. The chemical industry requires 6.8 tons of salt, the food industry needs 535 thousand tons, and other industries amount to 740 thousand tons of salt.

The national salt demand figure which reaches 4.5 million tons is not comparable with national salt production which is predicted to only be around 1.43 million tons. If the government only relies on local salt production there will be a very large salt crisis. At least $75 \%$ of national salt needs will not be met. This has caused the government to issue import permits of 3.016 million tons for industrial salt in 2018.

The salt quality of the local industry which is produced by the majority has a low quality. Industrial salt that meets the Indonesian National Standard (SNI) contains at least $97 \%$ $\mathrm{NaCl}$, maximum water $\left(\mathrm{H}_{2} \mathrm{O}\right) 0.5 \%$, maximum $\mathrm{Ca} 0.06 \%$, maximum $\mathrm{Mg} 0.06 \%, \mathrm{SO}_{4}$ maximum $0.2 \%$, minimal $\mathrm{KIO}_{3}$ $30 \%$, Cd maximum $0.5 \mathrm{mg} / \mathrm{kg}$, Pb maximum $10 \mathrm{mg} / \mathrm{kg}$, maximum $\mathrm{Hg} 0.1 \mathrm{mg} / \mathrm{kg}$, maximal $0.1 \mathrm{mg} / \mathrm{kg}$, and waterinsoluble maximum $0.5 \%$. While the quality of local salt on average needs to do washing and purification to achieve these standards.

Erratic weather and inadequate technology are the main factors of weak local salt production. High rainfall and high humidity also increase the crystallization process of the salt 
making process. While the process of making local salt is not yet touched by technology, the quality and quantity of local salt are still low. Rainfall in 2016 is very high due to the phenomenon "la nina", so that salt production cannot be maximized. Rainfall is the main element in the salt production process [2].

To overcome the low local salt production, one of the efforts that can be done is the touch of technology in the production process. Salt making is a series of processes that can intensify if sweetened. The quantity and quality of salt can increase if the factors that inhibit production can be overcome to be minimized. To minimize it can be done the method of making semi-modern local salt.

The purpose of the method of making semi-modern local salt is to make a method of making salt that can produce good quality and quantity and fast production time. Besides that, it is also to produce salt that is suitable for consumption and has the appropriate $\mathrm{NaCl}$ content. While the benefits for farmers is to provide innovative methods of making salt that produce salt with good quality and quantity, help farmers problems regarding methods that are resistant to all weather, and add a reference method of making salt with a faster production time. The benefit for the community is helping the community by meeting national salt needs and directing the community to use and love domestic products.

\section{METHOD}

\section{A. Study of literature}

To find out the technology that needs to be applied, it is necessary to conduct a literature study first. Literature study is carried out by directly observing the location of local salt-making ponds. At the location of salt ponds, a direct survey is needed on the method of making local salt. Observation and documentation studies can also be done to increase data collection. And to increase the up-to-date data, there can be direct interviews with salt farmers in the location and dig up information about constraints in the method of making local salt.

In salt ponds in Pasuruan, East Java salt farmers still use traditional methods. So that during the rainy season arrives farmers must harvest their salt early. Of course the results will not be maximized. Because if harvested too early these crystals will have little $\mathrm{NaCl}$. Even though $\mathrm{NaCl}$ is a very important chemical in salt. Salt production in this area is only during the dry season, during the rainy season the land or salt ponds will be idle, not used for anything.

The period of salt production in Indonesia in the normal dry season only ranges from 3.5 to 4 months plus a preparation period of 1 month, which is around June to October. Usually, the income during the salt season can only meet the needs for $7-8$ months, especially for salt farmers in rent or profit sharing systems. In general, salt farmers will work in other sectors during the rainy season [3]. The target of salt production per person in one season is $100,000 \mathrm{~kg}$ or 100 tons, assuming the productivity of salt ponds is 100 tons/ha, then one person must at least manage the pond area of 1 hectar [4].

\section{B. Prototype Design of Semi-Modern Local Salt Making Method.}

The resulting prototype is the design of salt ponds using semi-modern methods. There are several land modifications when compared to conventional salt ponds. Crystallization tables in real salt ponds usually range in size from $20 \mathrm{~m} \times 10$ $\mathrm{m}$, while the prototype ranges from $75 \mathrm{~cm} \times 23 \mathrm{~cm}$. So the actual area ratio with the area of the prototype reaches 200 $\mathrm{m}^{2}: 0.1725 \mathrm{~m}^{2}$, equivalent to $1,159: 1$.

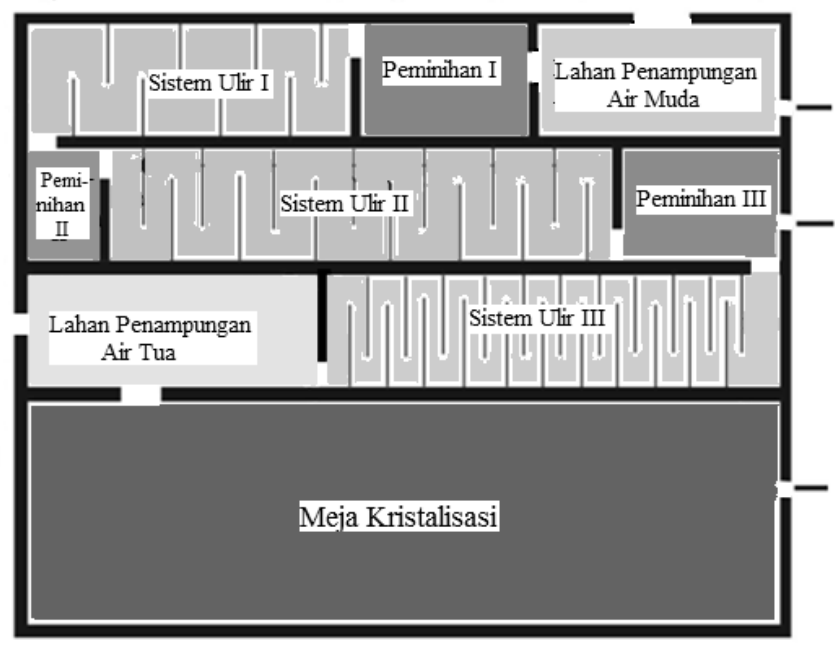

Fig. 1. Design of the main prototype parts

In accordance with Figure 1. the parts of the main prototype framework consist of 9 plots of land which includes:

1. Young water storage area, the young water storage area is the first land used to accommodate sea water when first entering the prototype land. The total capacity of this land is 2.04 liters of water.

2. Land use 1, area 1 is the first evaporation area after the water is finished conditioned in a young water reservoir. In the field of excitation 1 , the salinity level of seawater was tested to show $5-6^{\circ} \mathrm{C}$.

3. Threaded system 1 , the screw system is a windingshaped flow plot with boundaries that are of a certain width. In the screw 1 system, the width between the screens is $4 \mathrm{~cm}$. The function of the winding shape is to extend the flow so as to speed up the evaporation process so that the Baume level is higher.

4. Demand land 2, the size is narrower than 1 land that is $14.4 \times 12 \mathrm{~cm}$. In this field, the salinity was tested to show $10-15^{\circ} \mathrm{Be}$.

5. Threaded system 2, the size of the bulkhead in screw 2 system is $3 \mathrm{~cm}$.

6. 3 inland, 3 in size are the same as in 2. On this land, the salinity is tested up to $18-21^{\circ} \mathrm{Be}$ Excretion land 3 has a special process, which is the addition of $0.1 \mathrm{~N}$ $\mathrm{NaOH}$ and $20 \% \mathrm{Na}_{2} \mathrm{CO}_{3}$.

7. Threaded system 3 , the size of the bulkhead in the threaded system 3 is $2 \mathrm{~cm}$.

8. Old water storage area, old water storage area is needed so that old water that is ready to be 
crystallized can still be stored first if the crystallization table is not ready for use.

9. Crystallization table, the crystallization table is used to place crystallization of seawater into salt. The size of the crystallization table on the prototype is $23 \mathrm{x}$ $75 \mathrm{~cm}$, so the area is $0.1725 \mathrm{~m} 2$.

At the crystallization table also added geomembrane. Geomembrane from HDPE (High-Density Poly Ethylene) is expected to accelerate evaporation and shorten crystallization [5].

In addition, there is also a roof of crystallization tables, filters, and additional devices. The crystallization table roof serves to hold the heat trapped in the crystallization table so that the heat in the crystallization table can be maximized. Another function of roof crystallization is to maintain a crystallization table from weather anomalies. For example, when the rain falls, the result of crystallization is not damaged by rain.

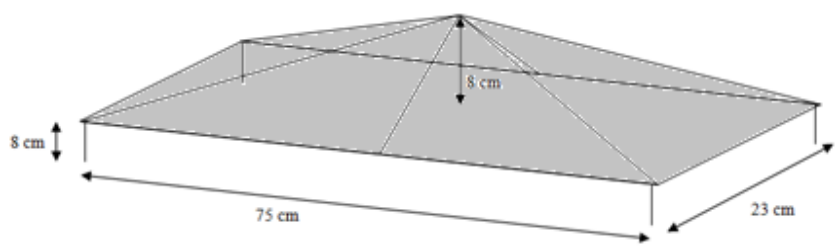

Fig. 2. The roof of Crystallization Table

The filter consists of the main material of a pipe with a length of $5 \mathrm{~cm}$ with the composition in it starting from the starting sequence including fibers, rocks, and sponges. The filter will be installed between the road to and out of the screw system. Following is the design of the filter.

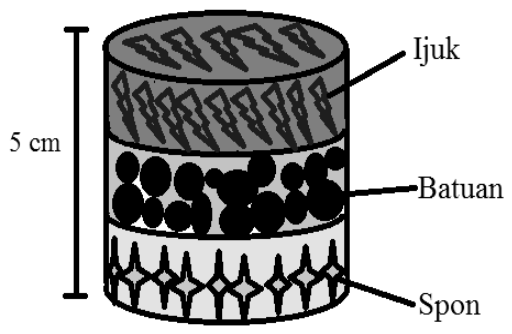

Fig. 3. Filter

Additional tools needed are in the form of 1) water outlet, 2 ) prototype base, and 3) geomembrane. For the water outlet made of faucets mounted on the sides of the bottom of the prototype wall as much as 4 pieces. As for the prototype base using white cement. White cement is coated on a prototype base with different heights. Starting from the young water storage area to the old water reservoir, the height is decreasing. This serves to provide access to the natural flow of seawater. Geomembrane is needed to cover the base of the crystallization table. This water-resistant black plastic geomembrane will maintain heat so that the evaporation process can take place more quickly.

\section{Steps of Semi-Modern Salt Making Method}

The steps for applying prototype use include:

1. Flowing 1 liter of water to the young water reservoir through a filter. The salinity was tested to show $3-4^{\circ}$ C.
2. While waiting for the first stream to be processed, if the water storage area is empty, 1 liter of seawater can be flowed again into the second stream, and so on.

3. The young water is flowed to the field 1 for the salinity level to show $5-6^{\circ} \mathrm{C}$.

4. Young water flowed through the screw system 1 through the filter until the salinity reaches $6-9^{\circ} \mathrm{C}$.

5. The water is collected in the 2 nd field of water. The salinity level is tested to show $10-15^{\circ} \mathrm{C}$.

6. Water flowed through screw 2 system to show 15$18^{\circ} \mathrm{C}$.

7. Water is collected in the Wasteland 3. The water is tested for salinity until it shows $18-21^{\circ} \mathrm{C}$. In addition, there is the addition of $0.1 \mathrm{~N} \mathrm{NaOH}$ and $20 \% \mathrm{Na}_{2} \mathrm{CO}_{3}$. The water is left to form until the precipitate is formed, then flowed to the next field.

8. Water is separated from sediment that is formed and flowed to the next screw system until it shows 21 $23^{\circ} \mathrm{C}$.

9. Water is stored in an old water reservoir. Water can be called old water and needs to be tested for its salinity. Old water can only be continued if the salinity reaches $23-25^{\circ} \mathrm{C}$.

10. Old water has flowed to the crystallization table with conditions $25-29^{\circ} \mathrm{C}$. 11) Salt crystallization and test results.

\section{RESULT AND DISCUSSION}

The application of technology that has been done is designing traditional salt ponds into semi-modern salt ponds. Experiments on the application of this method have been carried out on the Campus Campus 3 of Malang State University, Blitar from April to July. The design of making modified salt into semi-modern aims to intensify the function of each plot of land. Local salt-making land must at least consist of seawater in and out channels to the ponds, young water storage areas, waste fields, and crystallization tables.

In addition to modifying the pond design, production methods also need improvement. Salt-making methods generally consist of the flow of seawater to salt ponds, processing of seawater in the drainage area, drainage of seawater to the crystallization table, crystallization process, and harvesting. With the method of semi-modern salt making, there is a control of seawater quality, filtration in water channels, purification of impurities using $\mathrm{Na} 2 \mathrm{CO} 3$ and $\mathrm{NaOH}$ solutions. This method will increase local salt production.

To reduce impurities in salt can be done by a combination of the washing process and rapid dissolution at the time of making salt. While the elimination of impurities from salt products can be done by a chemical process, which is reacting with $\mathrm{Na}_{2} \mathrm{CO}_{3}$ and $\mathrm{NaOH}$ to form $\mathrm{CaCO}_{3}$ and $\mathrm{Mg}$ (OH) 2 deposits.

In the semi-modern salt-making method, it takes less time than the method of making local salt and the results obtained are more. Starting from the entry of water into the young water reservoir to get to the old water reservoir takes 10-15 days. And at the crystallization table takes 5-8 days. 
While the yield of salt crystals obtained is equivalent to 185 tons/ha.

The next step is that salt must be analyzed to determine the $\mathrm{NaCl}$ content with the argentometry method. The levels of sodium, magnesium, and calcium in salt products were tested using Atomic Absorption Spectroscopy (AAS). The results of the feasibility test of the salt produced by the method of making semi-modern local salt are having a salt content of $97.27 \%$.

\section{CONCLUSION}

The method of making semi-modern local salt can produce salt with better quality and quantity compared to traditional methods of making local salt. The quality of industrial salt from the semi-modern method meets industrial salt SNI which is $97.27 \%$ and the quantity is more than the traditional method of 185 tons/ha. While the time needed is around 30 days. This can support national salt needs so as to minimize dependence on imported salt.

\section{REFERENCES}

[1] Kemenperin. 2018. Pemerintah Siap Serap Garam Industri Rakyat 1,43 Juta Ton. (Online) http://www.kemenperin.go.id/artikel/10220 /Indonesia-Mampu-Produksi-Garam-Industri accessed at $19 \mathrm{Mei}$ 2018.

[2] Kurniawan, Tikkyrino \& Azizi, A. 2012. Dampak Perubahan Iklim Terhadap Petani Tambak Garam d Kabupaten Sampang dan Sumenep. Jurnal Masyarakat dan Budaya, 14(3), 499-518.

[3] Wahyono, A., Imron, M., Nadzir, I. \& Haryani, N.S. 2012. Kerentanan Penambak Garam Akibat Perubahan Musim Hujan di Desa Randutatah, Kabupaten Probolinggo. Jurnal Masyarakat \& Budaya, 14(3), 519-539.

[4] Bramawanto, R. 2017. Desain dan Layout Tambak Garam semi Intensif Skala Kecil di Lahan Terbatas. Jurnal Segara, 13(3), 159167.

[5] Arwiyah, Zainuri, M., \& Efendy, M. 2015. Studi Kandungan $\mathrm{NaCl}$ di Dalam Air Baku dan Garam yang Dihasilkan Serta Produktivitas Lahan Garam Menggunakan Media Meja Garam yang Berbeda. Jurnal Kelautan, 8(1), 1-9. 